\title{
PEMANFAATAN TEKNOLOGI INFORMASI DAN KOMUNIKASI PADA PEMERINTAHAN GAMPONG (DESA) DI WILAYAH PESISIR KOTA LHOKSEUMAWE
}

\author{
Muhammad Fazil ${ }^{1}$, Awaluddin Arifin ${ }^{2)}$ \\ 1)Universitas Malikussaleh. email:mfazil@unimal.ac.id \\ 2) Universitas Malikussaleh.email: awaludin.arifin@unimal.ac.id
}

\begin{abstract}
ABSTRAK
Pemerintah mendukung pemanfaatan teknologi informasi dan komunikasi dalam pemerintahanan dari kota sampai ke desa (gampong). Tidak terlepas dalam wilayah pesisir yang selama ini dirasakan tertinggal. Studi mengenai pemanfaatan teknologi informasi dan komunikasi di tingkat gampong dalam wilayah pesisir kota Lhokseumae menjadi suatu hal yang perlu dilakukan. Penelitian ini bertujuan memberikan deskripsi dan menganalisa realisasi serta pemanfaatan teknologi informasi dan komunikasi pada pemerintahan gampong di wilayah pesisir kota Lhokseumawe. Fokus pada pemerintahan gampong Hagu Barat Laut Kota Lhokseumawe. Metode kualitatif dengan pendekatan deskriptif dilakukan dalam penelitian ini pada pemerintahan gampong di wilayah pesisir Kota Lhokseumawe, dimana penentuan informan penelitian dilakukan secara purposive sampling dan teknik pengumpulan data melalui observasi, wawancara, dan dokumentasi. Hasil penelitian mendapati bahwa realisasi dan pemanfaatan teknologi informasi dan komunikasi pada pemerintahan gampong di wilayah pesisir kota Lhokseumawe telah mengalami beberapa perubahan dengan kehadiran teknologi komputer dan internet. Pemanfaatan aplikasi Microsoft office berfungsi sebagai pusat pengolahan, penyimpanan dan percetakan. Peningkatan produktivitas dan kecepatan dalam mengolah dokumen, surat menyurat dan laporan serta membagikannya kepada seluruh stakeholder dengan cepat (realtime). Selanjutnya pemanfaatan internet telah meningkatkan kualitas dan konsistensi hasil, memudahkan dalam mengedit, mengolah data, menghemat tenaga, dan sangat dipermudah pada administrasi perkantoran. Terutama dalam penerapan aplikasi ePlanning dan aplikasi Sistem Keuangan Desa (SisKeuDes).
\end{abstract}

Kata Kunci: Pemanfaatan, Teknologi informasi dan komunikasi, Wilayah Pesisir, Komunikasi Pemerintahan.

\section{PENDAHULUAN}

Kehadiran era komunikasi global ketika ini telah membuat perangkat teknologi informasi berupa internet bukan lagi barang asing. Akan tetapi kehadiran internet telah membuka akses jarak yang jauh makin dekat dan memberikan efesiensi waktu yang sangat berguna. Teknologi diperkenalkan untuk membantu memudahkan aktivitas manusia, yang kemudian berkembang 
memasuki sendi-sendi kehidupan (Pacey, 1983). Kemampuan untuk memanfaatkan teknologi informasi dan komunikasi dengan berbagai aplikasi dapat digunakan untuk kemudahan dan kelancaran segala urusan manusia, seperti penggunaan aplikasi web, email, media dan jejaring sosial, bahkan teleconference dan lain sebagainya.

Di Indonesia, UU No. 6 Tahun 2014 menjadi payung hukum utama dalam rangka pembangunan desa era baru. UU ini juga mengamanatkan beberapa faktor Teknologi informasi dan komunikasi dalam pembangunan desa. Ini paling jelas adalah Pasal 86 mengenai Sistem Informasi Desa, dan beberapa pasal terkait pemanfaatan Teknologi Tepat Guna. Program-program pembangunan desa perlu digagas oleh berbagi komponen dalam pemerintahan. Terutama dalam pemanfaatan teknologi informasi dan komunikasi di segala bidang pemerintahan desa dengan baik dan benar. Hal ini merupakan respons counter active atas arus globalisasi dan teknologi di berbagai bidang dalam pemerintahan sampai ke level terendah yaitu pedesaan.

Dalam pemerintahan, teknologi informasi dan komunikasi sendiri telah ada dengan berbagai macam program seperti: e-government, e-learning, ecommerce. Walaupun kontennya sendiri sangat bergantung pada penetrasi akses ke internet dan inovasi-inovasi baru software. Teknologi informasi dan komunikasi dapat memainkan peranan yang besar di dalam mendukung good governance melalui transparansi dan partisipasi masyarakat. Berlakunya Undangundang Nomor 14 Tahun 2008 tentang Keterbukaan Informasi Publik telah memberi ketegasan dalam hal ini. Dan ini sangat tergantung kepada pengelola pemerintahan dan peran aktif masyarakatnya sehingga good governance ini bisa direalisasikan dan bukan hanya sekedar mitos belaka.

Dalam penyampaian informasi pada warga masyarakat dengan berbagai latar belakang dan karakteristik, pemanfaatan teknologi informasi dan komunikasi adalah salah satu cara dalam meningkatkan dialog antar pemerintah dengan masyarakat. Baik itu dalam proses pelayanan administrasi maupun pelayanan publik guna membentuk pemerintahan yang lebih transparan. Hal ini juga bisa menawarkan potensi partisipasi masyarakat yang lebih luas untuk ikut serta dalam 
proses pembangunan daerah. Walaupun kemudian hadir kesenjangan teknologi dan digital antar wilayah dalam sesebuah daerah seperti belum meratanya infrastruktur, terbatasnya ketersediaan sumber daya manusia dan anggaran yang tersedia dalam penerapan teknologi. Selanjutnya berpotensi tidak menjadi prioritas utama oleh beberapa pemerintahan, khususnya pada pemerintahan tingkat desa (gampong).

Masyarakat pesisir di Indonesia, mempunyai kehidupan yang berbeda, menghadapi keadaan ekosistem yang keras, dan ketergantungan sumber kehidupan pada sumberdaya pesisir dan laut. Kehidupan dalam masyarakat pesisir terutama pesisir pedalaman masih dalam persoalan kemiskinan dan keterbelakangan. Hal ini tentu berkaitan dengan aspek ekologis, sosial, dan ekonomi, sehingga beberapa daerah komunitas perkampungan pesisir masih tertinggal. Persoalan utama adalah rendahnya taraf hidup dan akses yang terbatas akan aset dan sumber-sumber pembiayaan bagi kawasan pesisir adalah hal yang sering dijumpai untuk wilayah ini. Namun demikian sifat masyarakat pesisir yang cepat dan relatif terbuka terhadap pembaharuan, telah menunjukkan adanya peningkatan penggunaan teknologi yang pesat, terutama pada perkampunga pesisir yang teknosentrik, dimana fokusnya adalah ketersediaan teknologi lebih penting ketimbang kebutuhan pengguna teknologi itu sendiri (Nurudin, 2017;94)

Kota Lhokseumawe, dari karakteristik wilayahnya yang berbatasan langsung dengan laut Selat Malaka, mempunyai Koordinat : $5^{\circ} 7^{\prime} 0^{\prime \prime} \mathrm{LU} 97^{\circ} 2^{\prime} 0^{\prime \prime} \mathrm{BT}$, Total $181 \mathrm{~km} 2$ (70 mil²), Total Penduduk 179,807, Kepadatan 950/km2 (2,400/sq mi) dan dengan 68 gampong yang tersebar dalam empat kecamatan (www.bappedalhokseumawe.web.id, 2019 diakses 14 Agustus 2019), merupakan pemerintahan kota yang giat terus berupaya menerapkan teknologi informasi dan komunikasi dalam mendukung administrasi organisiasi agar lebih efektif dan efesien. Kota Lhokseumawe mempunyai beberapa gampong (desa) yang letaknya di wilayah pesisir pantai. Sebagaian besar daerahnya berada dalam wilayah pesisir secara karateristik pantainya landai atau dataran, Pesisir datar hingga landai menempati bagian mintakat kraton atau pantai cekungan. Beberapa desa atau gampong yang berada langsung berhadapan dengan laut selat Malaka seperti 
Ujong Blang, Ulee Jalan, Hagu Barat Laut, Hagu Teungoh, Hagu Selatan, Kampung Jawa Lama, dan Pusong Baru di Kecamatan Banda Sakti. Untuk Kecamatan Muara Satu ada Gampong Blang Naleung Mameuh, Rancong. Kecamatan Blang Mangat terdiri dari Kuala, Blang Cut, Mesjid Meuraksa, Jambo Timu, Tunong.

Wilayah Pesisir di kota Lhokseumawe sebagaimana wilayah pesisir lainnya yang merupakan wilayah yang khas karena merupakan pesisir pantai yang rendah permukaan antara daratan dan lautan, hal ini berpengaruh terhadap kondisi fisik dimana pada umumnya daerah yang berada di sekitar laut memiliki kontur yang relatif datar. Dari karakteristik ekosisitem Pesisir, wilayah pesisir kota Lhokseumawe merupakan wilayah di perairan laut dangkal pada umumnya seperti terumbu karang, padang lamun, dan hutan mangrove pada sisi rawa yang melindungi daratan dari lautan seperti tertera dalam UU No.4/1982 dan UU No. 5/1990. Dimana dari segi ekonomi, sosial dan budaya dengan penduduk mempunyai kegiatan sosial ekonomi yang berorientasi ke air dan darat, rata-rata penduduk dengan ekonomi lemah, dengan latar belakang pendidikan yang relatif terbatas, pengetahuan akan lingkungan sehat juga cenderung kurang, terjadi kebiasaan tidak sadar lingkungan serta kurang memperhatikan bahaya dan resiko. Walaupun beberapa kawasan sudah sadar dengan memanfaatkan kawasannya menjadi objek wisata seperti gampong-gampong yang berada di pesisir kecamatan Banda Sakti kota Lhokseumawe.

Dari observasi awal peneliti dalam pemanfatan teknologi terutama teknologi informasi dan komunikasi bahwa terlihat adanya komitmen pemerintah dalam memberi dukungan akan ketersediaan teknologi informasi dan komunikasi untuk mendukung pembangunan di wilayahnya, terutama peningkatan perbaikan proses administrasi pemerintahan gampong, pelayanan publik dan perbaikan database maupun dalam mendukung promosi parawisata bahari di kota Lhokseumawe terutama bagi gampong-gampong (desa) di wilayah pesisir laut Selat Malaka. Hal ini juga terlihat dari arahan penggunaan Anggaran Dana gampong (ADG) dan Dana Desa (DD) yang dibolehkan untuk alokasi inovasi gampong dan penerapan teknologi informasi dan komunikasi seperti penyediaan 
Portable computer (PC), modem, Projektor, kamera digital, pembelian data internet, hosting website, faximile dan smartphone yang dianggarkan dalam anggaran tahunan gampong. Dengan harapan penerapan dan pemanfaatan teknologi dengan baik akan mendukung perbaikan database, dukungan grafis, simulasi modeling, yang kesemuanya secara integral akan berguna bagi pengambilan keputusan dalam perencanaan, manajemen dan pembangunan gampong ke depannya.

Namun demikian dalam beberapa gampong masih terlihat bahwa ketersediaan peralatan teknologi yang dihadirkan oleh beberapa organisasi pemerintahan bukan hanya membawa perbaikan ekonomi dan sosial masyarakatnya, malah membawa pada bentuk lain dari eklusivitas. Dimana isu, sistem dan perubahan sosial masih menjadi fokus utama dalam gampong dibandingkan keinginan penerapan teknologi informasi dan komunikasi (Nurudin, 2017:94) yang kemudian melahirkan gagap teknologi dalam sistem pemerintahan gampong seperti aliran kebijakan masih dalam surat menyurat dan pelayanan public masih manual, database dan ketersediaan aplikasi website gampong (desa) yang tidak upto date.

Dari itu muncul permasalahan bagaimana pemerintah gampong (desa) dikawasan pesisir memanfaatkan teknologi informasi dan komunikasi dalam menunjang kegiatan pemerintahan, khususnya gampong dalam wilayah pesisir di Kota Lhokseumawe. Penelitian ini dirasa sangat penting untuk mengetahui pemanfaatan teknologi informasi dan komunikasi di tingkat pemerintahan gampong (desa), karena gampong (desa) dalam wilayah pesisir merupakan suatu wilayah pemerintahan yang biasanya tertinggal dalam hal pemanfaatan teknologi. Idealnya perkembangan suatu organisasi akan beriring dengan perkembangan teknologi dalam rangka menjalankan tugasnya serta mewujudkan visi dan misinya. Tentunya pemanfaatan teknologi informasi dan komunikasi sebagai salah satu media dalam pengelolaan informasi dan kebijakan dalam pencapaian visi tersebut. Walaupun pada sisi lainnya pemanfaatan teknologi informasi dan komunikasi suatu organisasi disebabkan oleh beberapa hal yang berbeda satu 
sama lain, antara lain: kebutuhan dan kepentingan organisasi itu sendiri, kebijakan pemerintah atau paksaan dari negara-negara maju.

\section{LANDASAN TEORI}

Teknologi Informasi dan Komunikasi secara umum adalah teknologi yang berhubungan dengan pengambilan, pengumpulan (akuisisi), pengolahan, penyimpanan, penyebaran, dan penyajian informasi (Kementerian Negara Riset dan Teknologi, 2006: 6). Teknologi informasi adalah suatu teknologi yang digunakan untuk mengolah data termasuk memproses, mendapatkan, menyusun, menyimpan, memanipulasi data dalam berbagai cara untuk menghasilkan informasi yang berkualitas, yaitu informasi yang relevan, akurat, dan tepat waktu yang digunakan untuk keperluan pribadi, bisnis,dan pemerintahan dan merupakan informasi yang strategis untuk pengambilan keputusan

Karakteristik dalam sistem Teknologi Informasi dan Komunikasi antara lain: Mampu menyediakan informasi, User Friendly, didesign dengan tepat untuk mempermudah akses informasi bagi pengguna, handal, siklus inovasi yang cepat, mempunyai waktu respon yang minimal, teknologinya beragam dan sudah stabil desentralisasi atau individualisme; penggunaan teknologi ini cenderung mengarahkan masyarakat menjadi individualis, karena kemudahan yang ditawarkan (Dedi. 2013). Selain itu teknologi komunikasi memiliki kategori karakteristik yang lain yaitu, Teknologi komunikasi adalah sebuah alat yang dilahirkan oleh sebuah struktur ekonomi, sosial dan politik, Teknologi informasi meliputi penggunaan alat bantu, manipulasi dan pengelolaan informasi. Teknologi informasi berkembang secara cepat sehingga tidak lagi dibatasi oleh ruang dan waktu. Informasi dapat disimpan dalam bentuk tulisan, gambar, suara dan lainlain. Dan Teknologi komunikasi merupakan alat untuk menambah kemampuan orang dalam berkomunikasi.

Komponen-komponen dalam Teknologi Informasi dan Komunikasi adalah: (1). Hardware (perangkat keras), yaitu perangkat keras komputer, berupa: CPU, storage, perangkat Input/ Output, terminal untuk interaksi, media komunikasi data. (2). Software (perangkat lunak), yaitu perangkat lunak 
komputer, berupa perangkat lunak sistem (sistem operasi dan utilitinya), perangkat lunak umum aplikasi (bahasa pemrograman), perangkat lunak aplikasi (aplikasi akuntansi). (3). Brainware (orang yang membuat, menggunakan dan memelihara sistem), , yaitu personil untuk pengelolaan operasi (SDM), meliputi Clerical personal (untuk menangani transaksi dan pemrosesan data dan melakukan inquiry(operator). (4). Database (penyimpanan data pada media penyimpanan komputer), yaitu beberapa keuntungan pemrosesan data berdasarkan database. Pencegahan redundansi data dengan menghindari pengulangan penyimpanan melalui struktur yang logik dan hemat (menghindari penyimpanan data berulang pada file). Selanjutnya konsistensi data dengan pengendalian duplikasi data maka tampilan data selalu konsisten karena dari sumber/lokasi penyimpanan yang sama. Selanjutnya (5). Telekomunikasi dan Prosedur, yaitu Telekomunikasi dan Prosedur merupakan langkah-langkah penggunaan sistem (Dedi, 2013).

Lebih lanjut, dalam perkembangannya globalisasi dan teknologi informasi dan komunikasi telah pun menghadirkan aliran proses komunikasi dalam perubahan-perubahan organisasi dan manajemen baik dalam pemerintahan maupun dalam lembaga bisnis. Naisbitt \& Aburdene (1985) mencatat berbagai perubahan paradigma aliran komunikasi sebagai akibat dari perubahan lingkungan global. Meijer (2008) melihat terjadinya berbagai perubahan paradigma aliran komunikasi mengandung implikasi pada perubahan paradigma organisasi dan manajemen baik pada struktur, strategi maupun budayanya. Perubahan-perubahan tersebut menuntut cara pandang yang berbeda terhadap kedudukan dan peran sumberdaya manusia. Cara pandang baru yang memposisikan sumberdaya manusia lebih strategis dan vital dari pada cara pandang lama. Sistem komunikasi pun mulai mengalir dengan berbagai pola, salah satu dari cara tersebut ialah dengan mendefinisikan struktur tersebut sebagai satu sistem laluan dimana pesanpesan mengalir atau aliran komunikasi dalam organisasi (Whitworth, 2006).

Terdapat klasifikasi pemanfaatan teknologi informasi dan komunikasi ke dalam tiga jenis, yaitu : pertama, teknologi informasi dan komunikasi sebagai media (alat bantu) administrasi pemerintahan. Kedua, teknologi informasi dan komunikasi sebagai sumber yakni sebagai sumber informasi dan mencari 
informasi. Ketiga, teknologi informasi dan komunikasi sebagai sistem pengelaolaan administrasi dalam pemerintahan (Praditya, 2014).

\section{METODE PENELITIAN}

Penelitian dilaksanakan di gampong pesisir dalam kecamatan Banda Sakti Kota Lhokseumawe, Aceh, yaitu Gampong Hagu Barat Laut, yang berfokus pada pemanfaatan teknologi informasi dan komunikasi di tingkat pemerintahan gampong (desa) untuk mendukung kegiatan pemerintahan terkait kelancaran administrasi, pelayanan kepada masyarakat, pengelolaan website, dan database gampong. Metode penelitian yang dipakai dalam penelitian ini bersifat deskriptif dengan menggunakan pendekatan kualitatif (Creswel, 1994). Metode penelitian ini dimaksudkan untuk memperoleh gambaran tentang pemanfaatan teknologi informasi dan komunikasi pada pemerintahan gampong di wilayah pesisir kota Lhokseumawe.

Teknik pengumpulan data melalui pengamatan (observasi), wawancara (interview), dengan penentuan informan berdasarkan teknik purposive sampling pada pemerintahan gampong di wilayah pesisir kota Lhokseumawe yaitu Gampong Hagu Barat Laut, yang meliputi aparatur pemerintahan Gampong, tokoh Masyarakat dan Masyarakat gampong. Selanjutnya kajian pustaka, yakni teknik pengumpulan data dengan mempelajari buku-buku, makalah, jurnal penelitian, dan bahan-bahan tertulis lainnya yang berhubungan dengan topik penelitian. (Sugiyono, 2004:129)

\section{HASIL DAN PEMBAHASAN}

Kehadiran Teknologi informasi dan komunikasi telah berdampak pada perubahan sarana dan prasarana penunjang administrasi perkantoran. Beberapa perubahan teknologi telah terjadi dengan kehadiran computer dengan keyboard, layar, prosesor, memory dan printer telah menghadirkan word processor yang digabungkan sebagai suatu sistem yang berfungsi sebagai pusat pengolahan, penyimpanan dan percetakan. Inovasi online dalam pemanfaatan teknologi informasi dan komunikasi kemudian telah membawa kepada keuntungan dalam 
penggunaannya seperti peningkatan produktivitas dan kecepatan dalam mengolah dokumen, surat menyurat dan laporan serta membagikannya kepada seluruh stakeholder dengan realtime.

Hasil dari penelitian tentang pemanfaatan teknologi informasi dan komunikasi pada pemerintahan gampong (desa) di wilayah pesisir kota Lhokseumawe lebih kepada kelancaran pelayanan administrasi kepada masyarakat, pelaporan keuangan gampong dan juga kelancaran hubungan pemerintahan baik internal maupun eksternal gampong. Dalam meningkatkan kualitas dan kuantitas pelayanan administrasi internal pemerintahan gampong, peralatan teknologi informasi dan komunikasi digunakan lebih pada proses mengubah data menjadi informasi atau pengetahuan. Pemrosesan data-data gampong ini mulai menggunakan komputer demi kelancaran proses administrasi dan pelayanan masyarakat secara cepat dan baik.

Dari observasi yang dilakukan terlihat beberapa tahapan dari pemanfaatan teknologi yang meliputi, tahap proses awal yang dilakukan adalah mendapatkan, mengumpulkan dan menginput data. Hasil wawancara didapati bahwa pengumpulan data dilakukan melalui dokumen dasar yakni dari formulir-formulir yang disi oleh masyarakat. Dokumen formulir ini membantu dalam penanganan arus data yaitu dapat menunjukkan macam dari data yang harus dikumpulkan dan ditangkap. Data dapat diinput dan dicatat dengan jelas dan akurat, menjadi file-file data dan folder data dengan pemberian nama di komputer. Proses pengumpulan data dilakukan untuk mempermudah administrasi gampong dan memudahkan dalam melakukan pekerjaan dalam sistem informasi serta pengolahan data. Walaupun beberapa fungsi dan bagian kerja dari aparatur di pemerintahan gampong terlihat belum semuanya lancar dengan pekerjaan tersebut.

Dalam tahapan menyimpanan data di Gampong Hagu Barat Laut, dilakukan demi menghindari terjadinya kehilangan data atau misalnya perangkat komputer mengalami error. Menyimpan data selain langsung di harddisk computer juga dilakukan dengan menggunakan flashdisk. Observasi peneliti melihat bahwa yang dilakukan di Kantor gampong ini, aparatur Gampong sangat mudah dalam melakukan penyimpanan data. Hal ini dirasa penting dalam 
menyimpan data dan juga mudah dalam mencari kembali data yang sewaktuwaktu dibutuhkan karena dapat disimpan dalam bentuk soft file dalam computer maupun disimpan juga dalam flashdisk. Penyimpanan data merupakan serangkaian tugas pemrosesan data yang sangat dibutuhkan. Menyimpan data dilakukan setelah data didapat. Data tersebut kemudian disimpan supaya data tidak hilang dan mudah dalam menemukan kembali sewaktu dibutuhkan.

Data yang baik tentunya tidak hanya untuk disimpan namun dapat ditransmisikan atau dapat distribusikan dari satu orang ke orang lain. Transmisi data melalui proses pengiriman data dari salah satu sumber data ke penerima data dengan menggunakan komputer/media elektronik. Di gampong Hagu Barat Laut, proses ini sudah mulai berjalan walaupun data yang ditransmisi menggunakan flasdisk. Belum memanfaatkan wireless atau jaringan intranet dan internet yang ada. Hal ini disebabkan belum semuanya aparatur gampong mempunyai pengetahuan dalam penggunaan wireless atau jaringan intranet dan internet dalam proses pengiriman data dan juga melalui aplikasi e-mail dan sebagainya. Padahal gampong ini sudah berlangganan jaringan internet Speedy dari PT. Telkom. Penggunaan internet selama ini hanya untuk mengambil data-data lewat blog, website dan lain-lain, yang itu dirasakan perlu untuk format dan model atau bentuk surat menyurat dan bahkan data-data lainnya yang penting bagi pemerintahan gampong, seperti aparatur gampong mengambil data kependudukan di internet melalui website kependudukan yang sudah disediakan oleh dinas kependudukan dan lainnya. Penggunaan internet belum dipakai untuk aplikasi atau program online tertentu seperti pemanfaatan internet untuk pengiriman surat elektronik (e-mail) dan aplikasi online lainnya.

Pemanfaatan teknologi informasi dan komunikasi di pemerintahan gampong idealnya juga harus dapat memanfaatkan internet untuk selain mendapatkan contoh data juga dapat melakukan proses memanipulasi data yang merupakan bagian dari tugas pemrosesan data. Proses ini adalah bagaimana memanfaatkan teknologi dalam mengedit data seperti mengubah data asli yang menjadi contoh untuk pembuatan data baru. Manipulasi yang dilakukan dapat berupa menambah, menghapus, mengganti, menyisip, dan menarik suatu 
informasi tertentu dan hasil dari penggabungan tersebut menimbulkan produk baru yang bisa dijadikan informasi. Penelitian mendapati bahwa aparatur di pemerintahan gampong Hagu Barat Laut belum dapat memanipulasi data secara baik walaupun sebelumnya ada aparatur yang telah mencoba membuat program sistem database gampong, namun saat ini database tersebut tidak dapat diupdate lagi dan jarang digunakan sebagai data informasi.

Data tersebut harus diedit kembali dengan manual di program office. Apalagi pada data yang lebih spesifik seperti program database gampong dan program rancangan website serta promosi gampong masih belum dimulai dengan serius dan belum ada penganggaran dana. Walaupun idealnya memanipulasi data sebenarnya perlu diketahui oleh aparatur pemerintahan gampong supaya data informasi yang baik siap untuk disajikan kepada internal pemerintahan maupun kepada masyarakat gampong. Sajian data kepada masyarakat dalam bentuk tampilan hard copy dan juga dengan bentuk tampilan soft copy menjadi penting dalam proses pelayanan. Dalam pemerintahan gampong Hagu Barat Laut, sajian data masih dalam bentuk hard copy saja. Dimana data tersebut diprint terlebih dahulu untuk mudah dalam mendistribusikannya. Seperti data informasi tentang profil gampong, administrasi gampong dan sebagainya. Dalam proses komunikasi secara internal pemerintahan gampong, lebih banyak menggunakan media jejaring sosial yakni WhatsApp (WA). Dimana aplikasi ini telah memudahkan dan membantu dalam pengiriman informasi dan komunikasi secara nonformal dalam internal pemerintahan gampong selama ini.

Pemanfaatan teknologi informasi dan komunikasi di sektor pemerintahan muaranya adalah kualitas pelayanan masyarakat dan stakeholder lainnya yang prima berbasis teknologi atau lebih dikenal dengan E-Government. Pelayanan publik sebaiknya bukan hanya mengikuti tren global, melainkan juga meliputi langkah strategis dalam upaya meningkatkan akses dan mutu layanan kepada masyarakat. E-Goverment mempermudah masyarakat mengakses berbagai informasi dan mendapat berbagai pelayanan tanpa harus datang langsung ke institusi pemerintahan terkait. Kualitas pelayanan akan meningkat dengan adanya pemanfaatan teknologi, karena dengan terciptanya good governance maka 
meningkatkan transparansi dan akuntabilitas lembaga-lembaga publik termasuk pemerintahan tingkat gampong di wilayah pesisir. Pemanfaatan teknologi infotmasi dan komunikasi di bidang pemerintahan dari gampong-gampong di wilayah pesisir tentunya tidak jauh berbeda dengan daerah perkotaan lain. Wilayah pesisir kota Lhokseumawe adalah wilayah yang dekat dengan pusat kota dimana pusat kota Lhokseumawe berada berhadapan langsung dengan laut Selat Malaka.

Pelayanan publik yang dijalankan di pemerintahan gampong Hagu Barat Laut belum sepenuh berjalan secara online sebagaimana harapan dalam pemanfaatan teknologi saat ini yang serba memudahkan. Hal ini terlihat dalam penggunaan alat teknologi informasi dan komunikasi masih bersifat mendukung kualitas administrasi internal saja dan belum online. Namun demikian pemakaian peralatan teknologi informasi dan komunikasi seperti computer, printer, projector dan internet sudah banyak membantu dalam proses pelayanan terutama dalam efesiensi waktu pelayanan yang semakin membaik. Pelayanan seperti surat-surat sudah memakai computer dan printer sedangkan internet hanya dimanfaatkan untuk mengetahui dan mencari bentuk atau format surat saja. Hal ini sangat membantu dalam meningkatkan kualitas dan konsistensi hasil, memudahkan dalam mengedit, mengolah data, menghemat tenaga, dan sangat dipermudah, cepat dan cermat. Walaupun demikian dalam pelaksanaan pelaporan keuangan gampong dan juga perencanaan pembangunan gampong, pemerintahan Kota Lhokseumawe telah menyediakan aplikasi tersendiri dalam format online tertutup antar lembaga di pemerintahan.

Pemerintahan kota Lhokseumawe dalam pemberdayaan teknologi di gampong-gampong dalam wilayahnya, membuat payung hukum dalam Qanun Kota Lhokseumawe nomor 1 tahun 2015 tentang Gampong, yakni terdapat dalam pasal 29 ayat 2 dalam kewajiban pemerintah gampong serta di pasal 30 ayat 2 dalam tugas dan wewenang Keuchik di gampong. Penyelenggaraan teknologi informasi dan komunikasi dilevel gampong terlihat dari beberapa pengadaan fasilitas penunjang teknologi informasi seperti dalam menjalankan sistem informasi manajemen administrasi dan keuangan Gampong selama ini, dimana 
mengimput data administrasi dan keuangan serta kearsipan gampong melalui aplikasi SIMAKDES yang selama tahun 2016 dan 2017 sudah online dan server datanya di Dinas Pemberdayaan Masyarakat kota Lhokseumawe.

Pada tahun 2018, Dinas Pemberdayaan Masyarakat Gampong (DPMG) Kota Lhokseumawe melakukan perubahan aplikasi terbaru yang bernama SisKeuDes yaitu Sistem Tata Kelola Keuangan Desa. Aplikasi keuangan desa (gampong) telah menggunakan Microsoft Acces sehingga lebih simple dan cepat diterapkan oleh pengguna aplikasi walau awam sekalipun. Penggunaan data base acces ini dirasa lebih mudah dalam mengatur dan mengolah transaksi dan data keuangan dalam kelompok skala kecil seperti pelaporan keuangan gampong (desa). Penggunaan aplikasi SisKeuDes di gampong-gampong dalam wilayah kota Lhokseumawe sangat membantu dalam meningkatkan pemanfaatan teknologi yang ada di gampong.

Aplikasi sistem keuangan desa (SisKeuDes) mengakomodir juga regulasi sistem keuangan tingkat desa dengan baik dan dirancang secara terintegrasi mulai dari perencanaan sampai dengan pelaporan. Secara umum, keluaran dari aplikasi ini adalah dokumen perencanaan, dokumen penganggaran, dokumen penatausahaan dan laporan-laporan tingkat gampong dan tingkat kabupaten/ kota. Pemanfaatan aplikasi ini diharapkan dapat mewujudkan pengelolaan Keuangan gampong yang transparan, akuntabel dan partisipatif. Nilai lainnya bagi para aparatur gampong adalah peningkatan kapasitas keilmuan sebagai unsur pelaksana teknis pengelolaan keuangan, yang membantu Keuchik sebagai pemegang kekuasaan pengelolaan keuangan gampong.

Selain aplikasi SisKeuDes, Pemerintah kota Lhokseumawe juga mulai menerapkan aplikasi e-Planning bagi semua gampong yang ada dalam wilayah kota Lhokseumawe tanpa terkecuali gampong Hagu Barat Laut. Program aplikasi ini digunakan untuk mengintegrasikan proses pembangunan menjadi sinergi antara visi dan misi pemerintahan, lembaga satuan kerja dan gampong-gampong di kota Lhokseumawe. Proses dalam program ini dimulai dari perencanaan pembangunan yakni usulan perencanaan pembangunan dari gampong-gampong, Satuan Kerja Pemerintahan Kota dan Lembaga badan lainnya dimasukkan secara 
online dan disusun dalam satu dokumen yakni e-Musrenbang. Kemajuan teknologi informasi dan komunikasi tentunya telah memberi banyak kemudahan bagi setiap orang untuk dapat berkomunikasi ke berbagai belahan dunia. Namun demikian untuk memanfaatkan produknya tersebut, perlu kemampuan khusus dalam memilih, mengolah dan menyerap informasi yang baik baginya.

Kebijakan dan program-program pemerintah sering menempatkan gampong (desa) sebagai objek bukan sebagai subjek, terutama program-program pemanfaatan teknologi informasi dan komunikasi hanya sampai pada tingkat kabupaten atau kecamatan. Pemerintah seharusnya memulai gerakan teknologi dari pemerintahan gampong (desa), agar gampong dapat menyelenggarakan pemeritahan secara baik dan mandiri, yang didukung dengan pemanfaatan teknologi secara baik, efektif dan efisien. Penerapan dan pemanfaatan teknologi yang baik tentunya akan membuka transparansi dalam pengelolaan pemerintahan. Pemanfaatan piranti lunak secara baik dan efektif akan menjadi sumber terbuka dalam kegiatan operasional (Mustika, 2011). Pemanfaatan teknologi informasi dan komunikasi juga menjadikan pemerintahan terbuka dan dapat membanguna koloberasi pembangunan bersama antar pemerintahan gampong dalam sebuah wilayah pemerintahan kabupaten/kota terutama pembangunan wilayah pesisir yang selam ini menjadi tolak ukur dalam pemanfaatan teknologi.

Oleh karena itu pemanfaatan piranti ini dapat juga untuk berkomunikasi dan membangun jejaring antar desa (Desa Madusari, 2013). Penyediaan informasi melalui pembuatan website/blog menjadi keperluan dalam diseminasi informasi kegiatan yang dilakukan oleh warga maupun aparat desa, meningkatkan penyebaran informasi sampai melewati batas wilayah (Gerakan Desa Membangun, 2014). Selanjutnya pemanfaatan sistem informasi untuk melaksanakan pelayanan publik, memperkenalkan potensi desa maupun menyosialisasikan pembangunan desa (Jahja, 2012) dan akhirnya sisi kemudahan dan tujuan teknologi inilah menjadi pangkal dari gerakan pemberdayakan dalam percepatan pembangunan oleh organisasi pemerintahan (Hanafi, 1987; Pala, 2009). 


\section{KESIMPULAN}

Pemanfaatan teknologi informasi dan komunikasi bagi pemerintahan gampong Hagu Barat Laut, kota Lhokseumawe telah berdampak pada perubahan sarana dan prasarana penunjang administrasi perkantoran. Beberapa perubahan teknologi telah terjadi dengan kehadiran komputer, printer, projector dan internet wifi. Dalam pemanfaatan teknologi informasi dan komunikasi di pemerintahan gampong dalam wilayah pesisir kota Lhokseumawe, pada pemerintahan gampong Hagu Barat laut, pemanfaatan teknologi informasi dan komunikasi lebih kepada kemudahan administrasi secara internal saja dan peralatan teknologi informasi dan komunikasi telah dimanfaatkan dalam menginput data ke dalam database gampong. Kemudian data tersebut dijadikan file-file data dan folder data dengan pemberian nama di komputer. Dalam penyimpanan data selain di harddisk komputer juga dilakukan dengan menggunakan flashdisk. Selanjutnya dalam transmisi atau distribusi informasi dan data juga masih manual dengan flashdisk (eksternal disk). Namun demikian, Hal ini sudah banyak membantu dalam proses pelayanan terutama dalam efesiensi waktu pelayanan yang semakin membaik, dimana pelayanan seperti surat-surat sudah memakai computer dan printer

Pemanfaatan jaringan internet lebih kepada pengambilan format bentuk surat menyurat, informasi terbaru dan data pemerintahan dari website pemerintah serta pelaporan keuangan dan perencanaan pembangunan secara internal antar lembaga pemerintahan Kota atau kabupaten dalam aplikasi yang disediakan oleh pemerintah kota/ kabupaten. Dalam berkomunikasi antar personal secara internal pemerintahan gampong, pemanfaatan teknologi informasi dan komunikasi lebih banyak menggunakan media smartphone secara pribadi dengan memanfaatkan aplikasi jejaring sosial yakni WhatsApp (WA). Aplikasi ini telah memudahkan dan membantu dalam pengiriman informasi dan komunikasi secara nonformal dalam internal pemerintahan gampong selama ini, seperti pemberitahuan, pengumuman dan undangan dalam bentuk file ke dalam group-group internal dalam aplikasi tersebut. 


\section{DAFTAR PUSTAKA}

Creswell, John W. 1994. Research design: qualitative \& quantitative approaches. London: Sage Publications.

Dedi. Pengertian Komponen dan Karakteristik. http://bk1120011dedi.blogspot.com/2013/12/ pengertian-komponen-dan-karakteristik.html. (Diakses 21 februari 2019)

Desa Madusari. 2013. Madusari Bergabung Dalam Jejaring Gerakan Desa Membangun.Tersedia di <http://madusari.desa.id/madusaribergabungdalam-jejaring-gerakandesa-membangun/>.diakses 22 Agustus 2019.

Gerakan Desa Membangun. 2014. GDM Siap Luncurkan Program Desa 2.0 di 100 Desa.Tersedia di <http://desamembangun.or.id/2014/08/g dm-siapluncurkan-program-desa-2-0di-100-desa/>.diakses 22 Agustus 2019.

Hanafi, Abdillah. 1987. Memasyarakatkan Ide-Ide Baru. Surabaya: Penerbit Usaha Nasional

Jahja, Ranggoaini. et. al. 2012. Sistem Informasi Desa: Sistem Informasi dan Data Untuk Pembaruan Desa.Yogyakarta: COMBINE Resource Institution (CRI).

John Naisbitt and Patricia Aburdene. 1985. Re-Inventing the Corporation: Transforming Your Job and Your Company for the New Information Society. New York: Warner Books.

Meijer, A. J. 2008. E-mail in government: Not post-bureaucratic but latebureaucratic organizations. Government Information Quarterly, 25:429_ 447.

Mustika, Maya Dewi. 2011. Desa Mandalamekar, Raih Kemandirian Teknologi dengan Open Source.Indonesian e-Learning Media.Tersedia di $<$ http://idelearning.com/ desamandalamekar-raih-kemandirianteknologidengan-open-source/.> diakses 22 Agustus 2019

Nurudin. 2017. Perkembangan Teknologi Komunikasi. Cet.1. Jakarta;Rajawali Pers.

Pacey, Arnold. 1983. The Culture of Technology. Massachusetts: The MIT Press.

Pala, Rukman. 2009. Teknologi Informasi dan Komunikasi dan Perannya dalam Proses Perubahan Sosial. Dlm: Majalah Publik Ilmiah Semi Populer.Ed.Desember 2009. Makassar: Balai Besar Pengkajian dan Pengembangan Komunikasi dan informatika.

Praditya, Didit. 2014. The Utilization of information and Communication Technology (ICT) By Government in Rural Level (88): 129-40. 
Sugiyono. 2004, Metode Penelitian Bisnis, Bandung: Alfabeta,

Whitworth, B. 2006. Internal communication. Dlm. Gillis, T. L. (pnyt.). The IABC Handbook of Organizational Communication: A Guide to internal communication, Public Relations, Marketing and Leadership, hlm. 205214. San Francisco: Jossey-Bass.

BAPPEDA Lhokseumawe. 2017. Profil Kota Lhokseumawe. http://www. bappedalhokseumawe. web.id (diakses 22 Agustus 2019) 